* Phd em Direito pela Universidade de Lucknow - Índia (2006). NET pela University Grant Commission.

New Delhi (1998). LLB em Direito pela Universidade de Lucknow - Índia (1998). LLM em Direito pela Universidade de Lucknow - Índia (1994). Pós Graduado em Direito Internacional e Direito Administrativo pela Universidade de Lucknow - Índia. Graduado em Direito pela Avadh University - Índia. Professor associado do Curso de Graduação, Pós- Graduação e Pré-PhD em Direito na University of Lucknow. Email:kahmad@rediffmail. com

\section{The Protection Of Minority \\ LANGUAGe: Whether A TOOL For Their Protection?}

\author{
A Proteção Da Língua Minoritária: \\ Qual Ferramenta Para Sua Proteção?
}

\section{Kamal Ahmad Khan*}

Como citar: KAMAL, Ahmad Khan. The protection of minority language: whether a tool for their protection? Scientia Iuris, Londrina, v. 21, n. 2, p.41-63, jul. 2017. DOI: $10.5433 / 2178-8189.2017 v 21 \mathrm{n} 1 \mathrm{p} 41$. ISSN: 2178-8189

Abstract: Language in its most developed forms is a priceless creation of man. It has always been a matter of slow evolution and no language can claim to have been born perfect or complete. Its evolution has marked its progress and in the evolution of human civilization languages have grown, decayed and even died, though not without leaving their impress behind in their offshoots. Language is the key to all intellectual and a great part of spiritual life. A common language makes possible free and familiar intercourse between two human beings and creates a bond between them. More than this each language, with its choice of words, its turn of phrase, its every idiom and peculiarity, is a sort of philosophy, which expresses the past history, the character, the psychological identity of those accustomed 
to use it. It is an instrument which, molded by the future. It is difficult for a foreigner to adopt the language of a people without in some way also adopting their habit of mind, and a child sucks in a sense of nationality within the very rhymes that it learns in the nursery. Language disappears by the destruction of the habits of their speakers, as well as by genocide, forced assimilation and assimilatory education, demographic submersion, and bombardment by electronic media, which may be called cultural nerve gas. The loss of language is part of the more general loss being suffered by the world, the loss of diversity in all things. In this background, the purpose of this paper is to assess the nature and extent of minority language rights, that are protected in human rights international treaties, measures that aims to protect speakers of minority languages from discrimination and to analyze the effectiveness of procedural and substantive measures adopted both at the national and international level.

Keywords: Language. Minority. Linguistic Rights. International Declarations and Conventions. State Practice.

Resumo: A linguagem em suas formas mais desenvolvidas é uma criação inestimável do homem. Sempre foi uma questão de evolução lenta e nenhum idioma pode dizer ter nascido perfeito ou completo. Sua evolução marcou seu progresso e, na evolução das linguagens da civilização humana, cresceram, deterioraramse e até morreram, embora não sem deixar 
suas impressões atrás em suas ramificações. A linguagem é a chave para todos os intelectuais e uma grande parte da vida espiritual. Um idioma comum possibilita a relação livre e familiar entre dois seres humanos e cria um vínculo entre eles. Mais do que isso, cada linguagem, com sua escolha de palavras, sua expressão de frase, é toda linguagem e peculiaridade, é uma espécie de filosofia que expressa a história passada, o personagem, a identidade psicológica daqueles acostumados a usá-la. É um instrumento que, moldado pelo futuro. É difícil para um estrangeiro adotar a linguagem de um povo sem, de certo modo, adotar seu hábito de pensar, e uma criança é um alvo de nacionalidade dentro das próprias rimas que aprende no berçário. A linguagem desaparece pela destruição dos hábitos de seus falantes, bem como por genocídio, assimilação forçada e educação assimilatória, submersão demográfica e bombardeio por meios eletrônicos, que podem ser chamados de gás nervoso cultural. A perda de linguagem é parte da perda mais geral sofrida pelo mundo, a perda de diversidade em todas as coisas. Neste contexto, o objetivo deste trabalho é avaliar a natureza e o alcance dos direitos linguísticos das minorias, medidas que visam proteger os falantes das línguas minoritárias da discriminação e analisar a eficácia das medidas processuais e substantivas adotadas tanto a nível nacional como internacional.

Palavras-chave: Idioma. Minoria. Direitos linguísticos. Declarações e convenções internacionais. Prática estadual. 


\section{INTRODUCTION}

There is a consensus regarding the meaning of the term language. The Roman House Unabridged Dictionary defines language as a body of words and system used for communication. The Oxford English Dictionary described the term, as the "whole body of words and methods of combination of words used by a nation, people, or race," for the purposes of expressing their thoughts, feelings, wants etc. If we pursue the dictionary definition of a language, as presented above, a linguistic group would be, a community of people having the same form of speech or simply a group with the same language. A linguistic minority would then be a group whose language does not enjoy a dominant position in the state. Ermacora (1983, p. 295), the legal expert has defined it as "[...] a group whose persons use a language in writing and or orally, in private and in public, which differs from the use of the language in a given territory and which is not considered the national language; the aim of this group is directed towards upholding and taking care of this language".

This definition sounds reasonable enough. The non-dominant position of the language concerned is not stated clearly or adequately here, but it is implicit in the expectation that the language should have national (official status). This is the pivotal point. After all, if the language of a minority should emerge at some point as the dominant language in a state, the group in question would cease to be a linguistic minority.

\section{MINORITIES AND CLAIM FOR PROTECTION}

There are many kinds of minorities in international law. The discussion with protection of minority language is concentrated with 
certain basic kinds of minorities like ethnic, religious and linguistic minorities. The protection of minority is meaningless unless linguistic rights of the minorities irrespective of its kinds, is protected. The word ethnic comes from 'ethnos', a Greek word that means 'race', culture, or people (RANDOM HOUSE, 1996, p. 489). Ethnicity thus describes the features or peculiarities of a people, a cultural, racial, religious, linguistic, national, etc. (RANDOM HOUSE, 2002, p. 665). International Encyclopedia of the Social Sciences (1962, p. 178) defines it as ethnology has come to mean comparative study of documented and contemporary cultures and has largely excluded their bio- anthropology, archeology, and linguistics.

Thus, an ethnic minority is defined as a social group that shares "a common and distinctive culture, religion, language or the like." As the word 'or' suggests in the above passage, the weight that should be given to the racial, religious, linguistic or cultural is unclear. That is why; it is not uncommon to see writers confusing an ethnic minority with a racial, or linguistic or religious one.

Article 27 of the Covenant on Civil and Political Rights addresses itself to persons belonging to "ethnic, linguistic, or religious minorities and their rights" to enjoy their own religion or to use their language," prompting some writers to agree that the order of the words used suggests that ethnicity reflects culture.

It is difficult to understand culture in isolation from religion and language. Similarly describing an ethnic group without regard to its linguistic and religious characteristics is not justifiable.

The practice of states is no less bewildering. For example, Jews are treated in Hungry as an ethnic minority in Iran as a religious minority (UNGARISCHES INSTITUT, 1992), and in France as neither of the two. 
The Government of Trinidad and Tobago, India, Malta, Benin, France and Republic of Korea have mentioned that the phrase 'ethnic minorities' has no practical meaning or applicability in their countries. ${ }^{1}$ The most central and South American government has said that they have only one type of ethnic minority, namely the descendants of the natives ${ }^{2}$. In Portugal and Spain, only one type of ethnic minority is said to exist, the "Roma". However, there are states that admit to possessing a number of ethnic minorities, as many as fifty or more ${ }^{4}$.

From the history of human communities, the formation of an ethnic group has not always been triggered by a single factor, be it language, religion or culture. Thus whereas in eastern and central Europe it was language that played a central role, in the Muslim world it was religion. As Kemal Karpat (1985, p. 97) emphasizes:

Ethnicity, or ethnic identity, may have certain tangible roots such as language, religion, education, organizational membership, personal identification with a group, media use etc. However, the operational or practical dimension of ethnicity, that is, its effects, are determined to a very large extent by the sociopolitical system and its ideology.

However, an ethnic group is composed of persons that share the same cultural identity as reflected in their values, traditions and customs. Such persons, generally, are unified by a common language or religion, and sometimes even by a common ancestry. However, to be accepted

1 The views expressed by governments of Trinidad and Tobago (E/CN.12/1989/SR.19, p. 2); The Republic of Korea (CCPR/C/68/Add. 1, p. 70); India (CCPR/C/37/Add. 13, p. 29); Benin (E/CN.4/1994/72, p. 9).

2 The statements of the Governments of Columbia (E/CN.4.2/1992/37/Add. 1, p. 5), Nicaragua (ORHRC $1989 / 90$, v. 11, p. 221).

3 CCPR/C/58/Add. 1, p. 37.

4 The Vietnamese report, in CCPR/C/26/Add. 3, p. 31. 
as ethnic minority a group should also satisfy other prerequisite, than possessing a cultural identity, such as being in a non-dominant position.

Since culture, religion and language internet with one another, the dividing line between such groups can sometimes be hard to discern (MACARTNEY, 1968, p. 7). Religion is a powerful force in shaping the culture and traditions of religious communities. As result, it is used, and continues to, capitalized by politicians for political or other objectives. Governments and men use or attack religion and language to justify the pursuit of power, prestige, or ethnic self-interest. It is precisely because both religion and language are important magnets around which individual cluster that they have and still are exploited during power struggles or for achieving national unity. What is guaranteed to minorities is merely the right to use their own culture and language and to profess their religion, although the kind of religion, language and culture that is protected has not been fully clarified. It is also not clear how states are to identify religious, linguistic and cultural groups.

The problem to protect minority language is linked to the contradictory consequences of democracy. As government by discussion, democracy calls for unity of language, but by giving all social classes from all parts of the state to participate in the government, it prevents linguistic and religious unity at the government level in multilingual states. Democracy may tend simultaneously towards uniformity and diversity.

In earlier days, when to govern was to order and when the order was transmitted verbally, the existence of many languages in a state did not create a serious problem. Modern states are different. Their administration is nationwide and highly formalistic, impersonal, very technical contacts with it are far more numerous, and consequently, the 
problem raised by linguistic minorities is for more complex.

Colonization and globalization have been another attack on language of the minorities. Western European languages appear to play an important function and have been claim to endanger the indigenous languages (MUFWENE, 2002, p. 167). European colonization of the past four centuries has contributed to the predicament of languages around the world, as it has introduced new socio-economic world order that have pre-empted the usefulness of some languages. Thus, the idea of modernization, rapid spread of new technologies and ideas through education and mass media, most of the leaders and planners had been molded, partly through their Western education, into believing in the superiority of the languages of the colonial powers. As the Ghanaian linguist Ansre (1979, p. 13) points out that linguistic imperialism has a subtle way of wrapping the minds, attitudes and aspirations of preventing him from appreciating and realizing the full potentialities of the indigenous languages. Victims of it are often convinced that despite the fact that large numbers of the public may not be able to speak the foreign language, it is good for the country.

Language does not have independent lives from their speakers. Speakers make their languages as they speak; and cultures are being shaped as members of particular communities behave in specific ways. These dynamic systems keep evolving as people behave linguistically and otherwise and as they keep adopting these systems to new situations. Thus languages co - evolve with their speakers. Language shift, which is the main cause of language endangerment and death, part of this adoptive co- evolution, as speakers endeavor to meet their day to day communicative needs. Linguistic changes are not bringing about cultural changes but it echo cultural changes. Language shift is no more than an 
adoptive response to changes in a particular culture, most of which have been identified as a socio-economic ecology. Takes the case of Sanskrit, the pride of Hindu culture had become a dead language in the time of Buddha, not in the sense that it was forgotten but in the sense that it was not in common use. Similarly Latin, the language of the learned and symbol of cultural unity in Europe is now a dead language and it is reduced to be used in the religious ceremonies and ceremonial functions of European universities (WADIA, 1991, p. 19). Similarly Persian and Urdu were the court language during Mughal period in India but now these minority languages have been reduced to poetic language, generally used in public gathering of mushayra.

Thus, argument for language maintenance, without arguments for concurrent changes in the present socio-economic ecologies of speakers seems to ignore the centrality of native speakers to the whole situation.

Another argument raised towards monolingual policy, is to bring national unity. Hans Dua (1985, p. 177) points out that language policies followed in many under developed countries favor the colonial languages of wider communication and ignore the multilingual reality of linguistically heterogeneous developing nations by inculcating one language policy for national unity. Debi Pattanayak (1988, p. 380) answers the question whether a country of many languages in not always threatened by disintegration in affirmative and argues that it is in the same sense that a plural world is always threatened by disintegration. No more, no less. If this leads one to the position that all languages in the world should give way to a single language, all religions should merge into one, all ethnicities should merge and fuse into one, is arguing in favor of a reductionism which fraught with serious consequences for the survival 
of humanity. Ecology shows that a variety forms is a prerequisite for biological survival. Monocultures are vulnerable and easily destroyed. Plurality in human ecology functions in the same way. One language in one nation does not bring about equality or harmony for members or groups of the nation.

\section{APPROACHES FORPROTECTION OF MINORITY LANGUAGE}

The approach supported by Perry Killer (1996, p. 59) is based on the notion that language is a fundamental element of personal identity. If so, then there must be congenial supportive cultural and linguistic environment for individual's personal development. Such environment is also necessary for members of cultural and linguistic majorities. In this context the traditional model of equality that attempts to ensure freedom from discrimination or unwarranted interference, is not sufficient to ensure the members of cultural and linguistic minorities the same range of possibilities in life as those of majority community. So the concept of intelligible differentia clause should be adopted in which the languages, religions and cultural practices of minority groups should be given proper respect in public culture and institution of a society with state support.

Another basis of linguistic right of the minorities is ecological one, under which linguistic diversities is valued.

The third basis of the right may be to protect the identity of the individual group and to establish stable society. Rita Izsak (2013) supporting the third argument emphasized in her report- "Language is a central element and expression of identity and of key importance in the preservation of group identity. Language is particularly important to linguistic minority communities seeking to maintain their distinct group 
and cultural identity, sometimes under conditions of marginalization, exclusion and discrimination."

The interpretation of 'All human beings are born free and equal in dignity and rights' as mentioned in Article 1 of the UN Declaration of Human Rights refers that equality in dignity and rights presupposes respect for the individuals identity as human being. Thus respect for a person's dignity is intimately connected with respect for the persons' identity and consequently for the persons language (DUNBAR, 2001). It has been further emphasized that both, rights of nondiscrimination and of maintenance and development of identity, serve to advance the primary function of human rights law, respect for human dignity: linguistic rights, and minority rights in general, ensure that minorities are able to realize and enjoy rights that the majority might be able to enjoy on its own (OSCE, 1999).

The Minority Language Charter also emphasizes that the protection of the historical regional or minority languages of Europe, some of which are in danger of eventual extinction, contributes to the maintenance and development of Europe's cultural wealth and traditions.

\section{OTHER INTERNATIONAL INSTRUMENTS MAKING SPECIFIC REFERENCE TO MINORITIES}

The Minorities Treaties of the League of Nations emphasized on the protection of minority language. The Polish Minority Treaty, 1919 provides that the Polish nationals, who belong to racial, religious or linguistic minorities, shall enjoy the same treatment and security in law or in fact as other Polish nationals. In particular, they shall have an equal right to establish, manage and control, at their own expenses, 
charitable, religious and social institutions, schools and other educational establishments with the right to use their own language and to exercise their religion freely therein ${ }^{5}$. The commentary on Article 9 of the treaty further emphasized that minorities were entitled to primary schools in certain specified instances and to private schools without limitation. The essential feature of such schools was the use of minority languages as the medium of instruction. The State could demand that the official language be studied, but it could not require that certain subjects be taught only in that language (ROBINSON, 1943, p. 215).

Article 13 of the Covenant on Economic, Social and Cultural Rights 1966 reiterates the substance of Article 26 of the Universal Declaration of Human Rights on the purposes of education that education shall enable all persons to participate effectively in a free society. Article 13 refers to the liberty of parents to choose schools, other than those established by the public authorities, which ensure the religious and moral education of their children in accordance with their own convictions.

Article 28 and 29 of the UN Convention on the Rights of the Child 1989 suggest that education should be directed to: the development of respect for the child's parents, his or her own cultural identity, language and values for the national values of the country in which the child is living, the country from which he or she may originate and for civilization different from his or her own. Protocol 1 of Article 2 of the European Convention on Human Rights and Fundamental Freedoms 1950 refers that no person shall be denied the right to education. In the exercise of any functions, which it assumes in relation to education and to teaching, the State shall respect the right of parents to ensure such education and teaching inconformity with their own religious and philosophical

5 Text in Protection of Linguistic and Racial Minorities by the League of Nations. Geneva, aug. 1927. 
convictions. Article 27 of the Covenant on Civil and Political Rights 1966 emphasized that persons belonging to ethnic, religious or linguistic minorities shall not be denied the right, in community with the other members of the group, to enjoy their own culture, to profess and practice their own religion, or to use their own language.

Article 4.3 of the UN Declaration on the Rights of Persons Belonging to National or Ethnic, Religious and Linguistic Minorities 1992, extending the meaning of Article 27 of the CCPR 1966 directs: "State should take appropriate measures so that whenever possible, persons belonging to minorities have adequate opportunities to learn their mother tongue or to have instruction in their mother tongue" (UNITED NATIONS, 1992).

The Minority Language Charter sets the importance of language rights firmly in the context of the positive value attached to cultural diversity for its own sake. The preamble to the Minority Language Charter provides that the protection of the historical, regional or minority language of Europe, some of which are in danger of eventual extinction, contribute to the maintenance and development of Europe's cultural wealth and traditions.

\section{CONCLUSION}

Thus, it is clear that both international law and human rights law provide protection to some extent to the language rights of the minorities, but it is clear that the present provisions falls well short of a comprehensive and coherent package. The obligation imposed on states with respect to the protection of minority language by the International Covenant on Civil and Political Rights and ECHR, Copenhagen 
Declaration, etc.... can be seen as a limited attempt to redress a gap in the UN Convention on the Prevention and Punishment of the Crime of Genocide of 1948, where it was decided not to include any provision which specifically addresses cultural genocide.

Likewise, the Framework Convention contains binding legal obligations but it was clouded by the proviso that this guarantee is subject to the measures taken by the states in pursuance of their general integration policy. Therefore, an integrationist policy towards minorities is not inconsistent with cultural and linguistic plurality.

State funding to minority institution established on religious basis in found discriminatory. Human Rights Committee found that a law that provided public funding to Roman Catholic schools but no other religious schools is violator of Article 26 of the International Covenant on Civil and Political Rights. The Committee found that the ICCPR does not oblige state parties to fund schools, which are established on a religious basis. The Committee recommended "[...] if a State party chooses to provide public funding to religious schools, it should make this funding available without discrimination. Thus providing funding for the schools of one religious group and not for another must be based on reasonable and objective criteria."

Similarly, in Scotland, there is a significant Urdu-speaking population, but State funding is limited to Gaelic medium educational institution on the ground that Scotland special measures of support excludes so-called immigrant languages.

Paragraph 63 of the explanatory report to framework Convention makes clear that reference to the use of the minority language in public life is restricted to its use in public places or in the presence of others, and is not concerned with communications with public authorities, or 
the use of the minority language in official context.

Article 27 of the ICCPR merely provides that States shall not deny members of the linguistic minorities the right use their own language, the positive measures by the State is also necessary to protect the identity of the minority and rights of its members to enjoy and develop their culture and language in community with other members of the group. Article 27 may impose positive obligation on State to support minority identity, it provides no guidance as to what measures are required. Hence States are left with wide discretion to decide the modalities of its application.

A considerable importance has been given on the role of minority language education. The rights of persons, belonging to minorities to maintain their identity can only be fully realized if they acquire a proper knowledge of their mother tongue during the educational process. This aspect requires the active commitment of educational institution, the right to set up schools without any guarantee of State support is hallow right in the context of minority language communities, which are often economically weak and vulnerable.

After independence from colonial rule, Universal Primary Education policy was adopted with the hope that the damage done by the colonial powers could be remedied. India wrote in her constitution of 1947 that a general eight year education for all was the goal by 1960 . During 1960s most regions of the world where UPE did not exist, UPE was seem as a human right which had been formulated already in Article 26 of the UN Universal Declaration of Human Rights which affirms every body's right to free and compulsory education at the elementary level. Nevertheless, the Declaration did not mention in which language this education should be conducted. However, there is not one word about 
language in the main body of the Addis Ababa report (COLONNA, 1975).

The negative attitude of the state towards minority language protection often coincides with public opinion within society. Aline Sierp (2003) finds that in most European countries with minority populations, being able to speak the majority language associated with modernity and development, whereas speaking a dialect or a minority language was regarded as an expression of backwardness and poverty. These prejudices are still prevailing in most societies and result in very centralized linguistic politics.

In 1990s, the principle of non-discrimination has been reiterated and reinforced in various instruments relating to minorities. This principle ensure that speakers of minority languages are not subject to discrimination at the hands of the States, it does not ensure that such persons obtain governmental services through the medium of their language.

Article 14 of the Framework Convention is more problematic. It provides that right of every person belonging to national minority to learn his or her minority language so that they can preserve their identity. However, the ambiguity lies in the fact that Paragraph 1 of Article 14 does not imply positive action of financial nature on the part of the state.

Article 14(2) of the Convention also gives an opportunity to the State to avoid protection to the minority language by changing demographic composition, because the right is available in area inhabited by persons belonging to the national minority traditionally or in substantial numbers.

The minority must put their sufficient demand in the area where the language is spoken traditionally or in substantial number, there is no indication in the convention of how sufficiency of demand is to be 
determined. This is again depends upon the discretion of the State to decide the sufficiency of the demand. The 'word endeavor' used in paragraph 76 of the Framework Convention is also misleading in respect of effectiveness of the protection. The paragraph says that States are only required to endeavor to ensure, as for as possible and within the framework of their educational systems. Furthermore, paragraph 75 expresses soft corner with the State giving it chance of alibi of poor finances and the technical difficulties associated with instruction of or in minority languages.

Minority Language Charter has broadened the measures of positive support of state. The Charter contains a wide range of provisions with respect to both the teaching of and the teaching through the medium of the regional or minority language at pre-school, primary and secondary levels, as well as the training of teachers and the monitoring of performance, but the requirements for achieving the above right is inconsistent with the notion that minority language rights are fundamental rights. The Charter gives States a wide discretion in the choice of positive measures of support, which they are obliged to implement. There is no guarantee that States will assure those obligations that are necessary and appropriate for minority language in question.

The promises made under Article10(2) of the Framework Convention asking the States to ensure as far as possible to use the minority language in relations between those persons and the administrative authorities, suffers from many weaknesses as the provisions in the Framework Convention on education is concerned. Here also the word 'endeavor' and the phrase 'as for as possible', financial and technical difficulties, provide wide discretion to the State concerned to implement the directives of the convention. The Judicial Authorities 
Charter also suffers from the weaknesses as stated above. The right access to minority language media must be understood as part of a broader right, namely the right to participate in cultural life, a right that is part of the Universal Human Rights canon. ${ }^{6}$ The legal provisions for the protection of linguistic minorities in media are consequently expected to be fairly well developed. The reality looks deferent.

The assurances, made under Article 19(2) of the ICCPR, Article 9 clauses 1,2 and 3 of the Framework Convention and Oslo Recommendations Regarding the Linguistic Rights of the National Minorities, to use their language in different kinds of media of expression for enhancing their cultural and linguistic identity, suffers from the trappings of discretionary words like 'adequate measures,' 'a substantive number of members' and 'fair share' etc.

So far as the provisions relating to rights of minorities in decision making affecting them, is concerned, they have also persuasive force on States. Whether it may be Article 2(3), 5(1) of UNGA Minorities Declaration, Articles 33 and 35 of the Copenhagen Declaration, Article 11 of the Minorities Protocol, or even the Minority Language Charter, imposes no significant requirement to involve the minority language community in decision making and linguistic planning process.

Thus the protection provided under various international instruments, though in patch work nature, have been able to create an awakening among the world community to consider the linguistic rights of minorities. Most of the States have been compelled to insert provisions in their constitutions for protection of minority language, culture and script. However, weak linkage between policy and planning render many

6 Article 1 of the 1992 United Nations Declaration on the Rights of Persons Belonging to National or Ethnic, Religious and Linguistic Minorities, adopted by General Assembly Resolution 47/135. Available in: <http://ungarisches-institut.de/dokumente/pdf/19920818-1.pdf>. Access in: 12 jun. 2017. 
policies ineffective. Convention and treaties adopted by international organizations and agreements recommending use of minority languages, without power to enforce them is ineffective. There are certain indicators that may measures the efficacy of minority language policy: The minority language should be linked with economy of the country, secondly, the will and attitude of the speech communities, without the interest of the speech community, any effort to promote institutional protection would be meaningless.

Thirdly, language policy of the government based on empirical and integrative socialistic studies will have effect (ROMAINE, 2002). Extra linguistic phenomena like ethno cultural settings of minorities, the historical, economic, and political developments, the speakers' loyalties and attitude and interest are important.

Factors such as linguistic changes, the amount of money spent, the number of conferences and meetings, and the active participation of the elite are not indicators of up lift of minority language. The object of language policy should be change that would result in spontaneous language use by large community of speakers.

However, making provisions and holding conferences to mourn on pathetic condition of minority language is not sufficient. It is the mindset of the policy makers and implementing authorities and the will of the Government, which can play a decisive role in bringing the expected result. A good provision may be a bad provision for minorities, if the persons working behind it, is of a bad lot. 


\section{REFERENCES}

ANSRE, Gilbert. Four rationalizations for maintaining European languages in education in Africa. African Language, 5 (2), p. 10-17, 1979.

COLONNA, Fanny. Instituteurs algériens 1883-1939. Office des Publications Universitaires, Algeria, 1975.

DUA, Hans. Language planning in India. New Delhi: Harman Publications, 1985.

DUNBAR, Robbery. Minority language rights in international law. ICQ, v. $50,2001$.

ERMACORA, Felix. The protection of minorities before the United Nations. Collected Courses of the Hague Academy of International Law, The Hague Academy of International Law, v. 182, 1983. Available in: <http://dx.doi.org/10.1163/1875-8096_pplrdc_ ej.9789024730698.247_370>. Access in: 12 jun. 2017.

IZSAK, Rita. Report. In: UN Human Rights Council, Geneva, 12 mar. 2013.

KARPAT, H. Kemal. The ethnicity problem in a multi-ethnic national Islamic State; continuity and recasting of ethnic identity in the Ottoman State. In: Ethnic Groups and the State edited by Paul Brass. New Jersey: Barnes and Noble books, 1985.

KILLER, Perry. Justice and ethnicity, 18 Oxford Journal of Legal 
Studies, 1998.

MACARTNEY, Carlile Aylmer. National states and national minority. New York: Russell \& Russell, 1968.

MUFWENE, Salikoko S. Colonization, globalization, and the future of languages in the twenty-first century. International Journal on Multicultural Societies, v. 4, n. 2, 2002.

OSCE. Report on the linguistic rights of persons belonging to national minorities in the OSCE area. The Hague: OSCE, 1999. Available in: $<\mathrm{http}: / / \mathrm{www}$.osce.org/henm/42060?download=true $>$. Access in: 12 jun. 2017.

PATTANAYAK, Debi P. Monolingual myopia and the petal of India lotus: do many languages divide or unite a nation? In: SKUTNABB-KANGAS, Tove; CUMMINS, James (eds.). Minority education: from shame to struggle. Clevedon: Multilingual Matters, 1988. p. 379-389.

PINKER, Steven. The language instinct: the new science of language and mind. London: Penguin Books, 1994.

RANDOM HOUSE. Webster's encyclopedic unabridged dictionary of the English language. New York: Random House Value Publishing, 1996.

Webster's unabridged dictionary. 2. ed. New York: Random House Reference, 2002.

ROBINSON, James A. (et. al.). Were the minorities treaties a failure? 
New York: Antin Press, 1943.

ROMAINE, Suzanne. The impact of language policy on endangered languages. International Journal on Multicultural Societies, v. 4, n. 2,2002 .

SIERP, Aline. Minority language protection in Italy: linguistic minorities and the media, Journal of Contemporary European Research, v. 4, n. 4, 2003. Available in: <http://www.jcer.net/index.php/jcer/article/ viewFile/120/117>. Access in: 12 jun. 2017.

SILLS, David L.; MERTON. Robert K. International Encyclopedia of Social Sciences. New York: Macmillan and Free Press, 1962.

UNGARISCHES INSTITUT. Statement by the government of the republic of Hungary on Hungarian minorities, 18 aug. 1992. Available in: <http://ungarisches-institut.de/dokumente/pdf/19920818-1.pdf $>$. Access in: 12 jun. 2017.

UNITED NATION. Declaration on the Rights of Persons Belonging to National or Ethnic, Religious and Linguistic Minorities. General Assembly resolution 47/135, 18 dec. 1992. Available in: <http://www. ohchr.org/Documents/Publications/GuideMinoritiesDeclarationen.pdf $>$. Access in: 12 jun. 2017.

WADIA, R. The sociology of language. Azad Academy Journal, Maulana Azad Memorial Academy, Lucknow, India, v. 1, n. 12, dec. 1991.

Como citar: KAMAL, Ahmad Khan. The protection of minority language: whether a tool for their protection? Scientia Iuris, Londrina, v. 21, n. 2, p.41-63, jul. 2017. DOI: 10.5433/2178-8189.2017v21n1p41. 
ISSN: $2178-8189$

Recebido em: 22/06/2017

Aprovado em: 21/07/2017 